\title{
Socio-Cultural Impacts of COVID-19 in Nepal
}

\author{
Gokarna Prasad Gyanwali, PhD*
}

\begin{abstract}
The COVID-19 pandemic has considerably distorted the social and cultural life of people on a global scale. It has a profound impact on the dynamics of human mobility, in \& out - migration, economy, and socio-cultural correlation that underpin population diversity. It seen that some of these effects are short-lived, but others will have long-lasting implications that can see in the future. The COVID-19 crisis is exposing the fragility of all our systems, our complex dependence upon one another, livelihood patterns and health, and healthcare as the most basic of human rights. Health security is one of the essential parts of social safety, which encompasses material or economic security; the security of life, and protection from violence and conflict, and these all are apprehensive and questionable in this pandemic. Like other developed and developing countries, Nepal is also facing the challenges contrived by the pandemic. This article describes the impacts of COVID-19 in socio-culture sectors and the diverse categories of the people of Nepal.
\end{abstract}

Keywords: pandemic, interdependence, isolation, deprivation, marginalization

\section{Introduction}

Corona viruses are a family of viruses that cause illness in humans and animals. Seven different types have found in people, including SARS - CV-2 (COVID-19), SARS - CV (Severe acute respiratory syndrome), MERS - CV (Middle East respiratory syndrome), HCV - NL63, HCV - 229E, HCV - OC43, HKU1. Corona virus disease (COVID-19) is a new strain discovered in 2019 and has not previously identified in humans (UN, 2020). It originated in Wuhan, Hubei province of China, a pandemic on 31 December, 2019. The virus has now spread to over 216 countries and territories across the globe and was characterized as a pandemic by the World Health Organization on 11 March, 2020 (WHO, 2020). As of 14 November, the global death toll surpassed 1,309, 431 amid more than 53 million cases. Over 37 million people have recovered from the disease worldwide, and total of 206, 353 cases; 1,202 deaths and 168, 129 have recovered cases in Nepal (World meter, 2020). 
The COVID-19 outbreak has been affected all segments of the society and the human population. Particularly those members of social groups in the most vulnerable situations, including people living in poverty, older persons, persons with disabilities, youth, women, and indigenous people. Early evidence indicates that the health and economic impacts of the virus are being borne inexplicably by poor people like homeless people, people without access to running water, refugees, migrants, jobless, and displaced persons. These people have been suffering disproportionately both from the pandemic and its aftermath - whether due to limited movement, fewer employment opportunities, increased xenophobia, etc. (UN, 2020). Most of the leadership of developed and developing countries have failed to control the impacts of pandemic. Politicians or leaders need to appear in control of the situation to avoid a panic that could be extremely damaging to society and societal values.

\section{Objectives}

The overall objective of this article is to assess the impact of COVID-19 in the socio-cultural sector of Nepal. The specific aim is to analyze the effects of COVOD 19 in health, education, politics, and different group of peoples of Nepal.

\section{Methods and data source}

Regarding the above - mentioned objectives, a descriptive method is applied in this study. The data used in the study is mainly quantitative, which are collected from different ministries of Nepal, Nepal Rostra Bank, UNO, UNDP, WB, and UNICEF, WHO, World meter and other national and international organizations.

\section{Social impacts of COVID- 19}

The COVID-19 pandemic has affected different sectors of society. About six months - long lockdown and curfew have hit Nepal's industries, tourism, entertainment, and transport sectors hard, slamming projected economic growth and pushing three in every five people working in small or micro - enterprises out of jobs. Working from home, attending online classes, and ordering groceries for home delivery are out of reach for the vast majority of Nepal's 30 million people (UNDP, 2020). It has affected all sectors of the economy, society, and cultural practices. Most of the countries, including Nepal, have decreased their budgets in socio-economic development like education, transportation, agriculture, industrial, and other sectors of human development and increased their budget only in health to control the COVID-19 impacts. That is why the majority of countries will think differently after this outbreak to improve their education, health, transport, and other social policies. (Lazily, 2020). Some of the significant social impacts of COVID-19 in Nepal are discussed here. 


\subsection{Political Sector}

Political scientists believed that the pandemic would strengthen the state and reinforce nationalism. Like the previous pandemic, it will also accelerate the shift in power and influence from West to East or vice-versa. In the initial phase of this pandemic, there was also a conflict between the USA and China, China and Australia, and the countries of the European Union. The USA has, for instance, adopted a nationalist approach with 'America first' in line with the Trump diplomacy since 2016 (Anton, 2019). China has used the crisis to display the advantages of its model, while Russia has accused of launching a disinformation campaign to destabilize Western democracies. Most countries have been closing their borders, banning exports of protective equipment, or securing exclusive rights for a new vaccine or drug may be beautiful measures for politicians: they can show that their citizens are prioritized. Nevertheless, these measures violate the rules for pandemic cooperation that countries themselves have committed to follow and might make other countries' responses even more challenging (Holsten, 2020).

The impacts of COVID-19 in the political sphere of the world have multiple ideas among the political theorists. It predicted that there will be three things that seem apparent. First, the coronavirus pandemic will change our politics, both within states and between them. Second, this is not yet the end of an interconnected world. The pandemic itself is proof of our interdependence (Menon, 2020). Third, science and technology have to do more things to combats such types of pandemics. Some political scientists believe that the pandemic will change the global political order. It will only accelerate a change that had already begun: a move away from U.S.-centric globalization to more China-centric globalization (Mabhubani, 2020). In the context of Nepal, there was a lot of a debate on the massive foreign aid package under the Millennium Challenge Corporation (MCC), Road and Belt Initiatives of China, the internal conflict of political parties (NPC \& NC), Nepal and India engaged in an intense border conflict triggering speculations about internal power-shuffling as well as bilateral diplomacy. This dispute involves a 40-square kilometer stretch of land on Nepal's far-western border with India, which is not far from China (Shakya, 2020). So, the pandemic has mostly affected the political scenarios of the world and inside the country.

\subsection{Educational Sector}

The COVID-19 pandemic has caused the largest disruption of education in history, having already had a near - universal impact on learners and teachers around the world, from pre-primary to higher level schools, technical and vocational education 
and training institutions, universities, adult learning, and skills development establishments. By mid - April 2020, 94 percent of learners worldwide were affected by the pandemic, representing 1.58 billion children and youth, from pre-primary to higher education, in 200 countries (UN, 2020). Similarly, UNESCO (2020) mentions that, the most severe impact of lockdown has on the education sector. In May, 95\% of households said their children had stopped going to school, and 52\% were not even studying at home. Only $29 \%$ had access to distance learning, but that only half were using it (UNICEF, 2020).

In the context of Nepal, around 76 million $(7,638,521)$ students and 8 million $(881,986)$ teachers, including primary, secondary, higher secondary, and university level (MoE, 2019), are out of the educational institutions. Due to the lack of internet facilities, poverty, rural, and weak network system, most of the children of Nepal are out of educational institutions. According to UNICEF (2020), only about $12 \%$ of Nepali children take classes online, or through radio/TV. Even here, the disparity is stark: while up to a third of children in higher - income households were using distance learning tools, only $5 \%$ in more impoverished families were doing so. The recent Child and Family Tracker survey by UNICEF (2020) Nepal shows that more than two-thirds of school children are underprivileged of distance learning. Only three out of 10 children have access to television, radio, and Internet-based learning platforms. Among them, only 80 percent of children use distance learning platforms for their learning activities. It indicates that even in the pandemic poverty gap is also the major factor to create the educational class in the developing world, including Nepal.COVID-19 has tested the limits of Nepal's education system, and much progress remains to be made to improve children's learning environment (WB, 2020).

\subsection{Health Sector}

Frontline health workers, including doctors, nurses, certified caregivers, lab technologists, and pharmacists, have been mostly affected by the pandemic, due to the inadequate supplies of PPE and other health - protective tools and lack of the good policies of the government. While trying to balance life as a healthcare professional and as a family member, dealing with highly infectious clients has led to guilt about potentially exposing their families to infection (Ramaci et al., 2020). Contracting COVID-19 has increased stigma and social discrimination among people. Some house owners have reported to evict nurses, doctors, and other medical professionals from their rental apartments, fearing the spread of the novel coronavirus in their neighborhood. The Chairperson of Nepal Medical Association, Dr. Lochan Karki mentioned that "health workers are being attacked, humiliated and intimidated due to 
fear that since they are infected, they will jeopardize the lives of others in society." $\mathrm{He}$ further added that,

People forget that they could get infected and others could turn against them.

There has been erosion in humanity, and this is a dangerous sign in itself for our society. These attacks on health care speak to the importance of adequate risk communication at all levels of society to reduce fear, stigma, and ultimately, violence (Cited in Poudel, 2020).

Against these social attitudes, health personnel have invested their time without compromise their own and family life. According to the Medical Council of Nepal (2019), there are 26346 doctors and 7758 specialists registered in Nepal. Among them, over 1000 health workers, including 180 doctors, have infected as of now. Hence, by understanding the disease, building trust, showing empathy to those affected health personnel, and adopting effective practical measures, people can save their dear ones (UNICEF, 2020b), and only we can fight collectively against COVID-19 effects in society.

\subsection{Social deviances}

The COVID-19 pandemic has drastically changed human life on a global scale. Nearly overnight, in countries worldwide, routines reduced to all, but a handful of activities, and daily mobility patterns became concentrated around our homes. Social distancing measures and lockdowns, for example, have had an impact on violent street crime, often linked to organized criminal activity. Crimes of opportunity thrive on routine activities (Wickes, 2020). National Academies of Sciences Report (2020) mentioned that "Social isolation has been associated with a significantly increased risk of premature mortality from all causes," the report found, including a "50 percent increased risk of developing dementia, 29 percent increased risk of incident coronary heart disease, 25 percent increased risk for cancer mortality, 59 percent increased risk of functional decline, and 32 percent increased risk of stroke." The mental health risks are also profound. The researchers reviewed dozens of studies and found a consistent relationship between social isolation and depression, anxiety, and suicidal ideation (Klein, 2020). Some of the deviances due to pandemic in Nepal mentioned on the following points:

\subsubsection{Suicide}

According to Durkheim (1897), suicide is any death which is the immediate or eventual result of a positive (e.g., shooting oneself) or negative (e.g., refusing to eat) act accomplished by victim himself. In particular, suicide can be understood as a kind of sociality, as a special kind of social relationship, through which people create meaning 
in their own lives (Staples \& Widger, 2012). It is a very crucial and treacherous issue in the contemporary world. Every 40s, one person dies by suicide, making global deaths due to suicide to 800,000 each year, out of these $79 \%$ are from low- and middle-income countries (WHO, 2018). World Health Organization reported that many of suicides occur during pandemic a crisis. The pandemic of coronavirus disease (COVID-19) has intense effects on the mental health of general people, and consequently, the suicide rate rises. Like other LMIC, Nepal has been experiencing increasing deaths due to suicide each year, with 5124, 5317, and 5785 suicides in the year 2017, 2018, and 2019, respectively. During the COVID-19 pandemic, suicide cases in Nepal have increased by $20 \%$, and the rate of mental health illness predicted to see a further rise after the pandemic (My Republica, 2020). In lockdown period, a total of 2,218 people committed suicide, a staggering rise in the cases. The number shows that at least 20 people committed suicide every day during the lockdown compared to 15 suicide cases a day in the last year. Before the lockdown, the number of suicide cases used to stand at an average of 400 per month (Neupane, 2020). Psychiatrists have linked suicide with the mental health of people, and sociologists/anthropologists linked it to the socio-cultural and political mentality who has forced to stay indoors during the lockdown, curfew, and personal distancing. The sudden economic recession, unemployment, poverty, and financial distress might lead individuals to contemplate suicide (Poudel \& Subedi, 2020), which also correlated with the pandemic.

\subsubsection{Child marriage}

Increase child marriage and girls trafficking is another social impact of COVID19, which is common in the third world like Nepal. The Malala Fund (2017), estimates that 10 million more secondary school girls worldwide could be out of school once the crisis has passed. The lockdown has affected education worldwide, and children have no alternative work in their home. During the lockdown period, the girls between the ages of 14-17 in rural areas mostly, the western part of Nepal, have run away from home to get married to classmates or local boys. Although the country has committed to ending child marriage by 2030, it raised the minimum age of marriage to 20 in the 2018 Civil Code. Yet more than $36 \%$ of girls continue to marry before they are 18 (Bhattrai, 2019). Lockdowns, school closures, and economic downturns linked to COVID-19 are disproportionately affecting girls, with reduced access to sexual and reproductive health services and a rising incidence of harmful practices (Anderson \& Gouch, 2020). It is reported that young girls are to be getting married by themselves, in an alarming circumstance. So, in the period of lockdown, the rates of child marriage get increased in comparison to the other familiar situations. 


\subsubsection{Gender - Based Violence and Women}

Gender violence was a growing problem in Nepal before COVID-19. The UNPFA (2020) suggests that 48 percent of women in Nepal had experienced violence at some point in their lives, with 27 percent of them experiencing physical violence. Besides, 61 percent of them had never told anyone about the abuse. Women Rehabilitation Center (2020) reported that 624 cases of Gender - Based Violence (GBV) between March to May from 55 districts during the lockdown period (Neupane, 2020). A study published in the Kathmandu Post mentioned that every ten minutes, a woman somewhere in Nepal dials 1145, the helpline operated by the National Women Commission (NWC), seeking assistance. The majority of these calls are made by survivors of domestic violence who are either looking to report incidents of abuse or calling to inquire about the support services offered by the group. (K.C., 2020). The mean score of the rigorousness of impact of COVID-19 for females is high due to their inability to find an alternative source of income, which is followed by the incapacity to pay loans, psychological problems, incapability to find a new job, and inadequacy to purchase the food (UNDP, 2020). Besides this, there are various causes like social, cultural, sexual, psychological, political, etc. of gender - based violence in Nepal.

\subsubsection{Rape cases}

According to the Nepal Police's latest statistics, 2,144 rape cases and 687 attempts to rape cases reported in 2019/20. In the past two months alone, as many as 420 cases of rape registered. Rape cases have surged mysteriously in Nepal despite the COVID-19 pandemic. According to Nepal Police, the number of other crimes decreased during the lockdown except for rape and suicide cases (Nepal Police, 2020). The survivors are often minors who are at high risk of being exploited. According to WOREC (2020), there were 367 cases of rape reported in the last six months (April/May to September/October 2020). Of these rape cases, 44 were gang rapes. The most upsetting fact revealed by the report is that of the total rape victims, 283 are girls below 18 years of age, including 39 victims between two and ten years (13 percent) and 244 between 11 and 18 years ( 86 percent) (cited in khabarab online). Most of these cases are in minors, which is very critical and dangerous. According to Rising Nepal, a 13-year-old girl was raped by a 20 - year-old boy; a 17-year-old girl was gang - raped by a group of nine men in Sunsari, an 8-year-old girl was raped by a 14-year-old boy in Rupandehi, and a 61-year-old father was arrested on the charge of raping his 16-yearold daughter on multiple occasions (Karki, 2020). These severe cases are the examples of the lockdown period which indicate the future trends of the Nepalese society and psychology of the people. 


\subsection{Vulnerable Group}

The Group of people who experience a higher risk of poverty and social exclusion than the general population are known as vulnerable people. Recently, People in Need (PIN) and Community Self-Reliance Centre (CSRC) has conducted a multisectoral needs assessment in 21 districts to assess the impact of COVID-19-related measures on the lives of vulnerable communities affected by earthquake and other natural disasters. According to the report, $65 \%$ of households reported reduced market access; $54 \%$ of households with access to the market could not make purchases as usual. Similarly, $65 \%$ faced food shortages, among which $51 \%$ had food supplies sufficient for 2.5 weeks or less; $87 \%$ experienced a decrease in payment or are currently without any income at all; $45 \%$ reported no or limited work opportunities for unskilled labor as one of the reasons, and $81 \%$ reported income loss as the most significant issue they are currently facing due to lockdown and COVID-19 (PIN, 2020). Like other disasters, the ethnic minorities, migrants, disabled people, and homeless peoples are more affected by this pandemic.

\subsection{Dalits}

Caste-based discrimination, untouchability, deprivation, poverty, etc., are the root cause of the problems Dalits face. Dalits in Nepal have been a socio-economically, culturally, and politically excluded and marginalized community for centuries, although they have large about 13.6 percent of the total population (CBS, 2014). Dalits are not homogenous; they have a wide range of diversity based on religion, geography, impairments, and other characteristics. The degree of impact caused by the COVID-19 pandemic also varies with these intersections. During the COVID-19 pandemic, few Dalits provided with some food items as part of relief packages. However, many more left behind in accessing these benefits due to the lack of information, and formal documents (Gahatraj, 2020). Dalits have been facing the problems of health facilities, quarantine and isolation in the pandemic. There are lots of discrimination events during the pandemic. A study conducted by Samata Foundation, 56 caste-based discrimination cases reported during the three-month lockdown period. Among them, eight caste-based discriminatory behaviors happened in the quarantine centers. A Dalit woman was beaten up by a Ward Chairperson during relief material collection in Mahottari district (Bishwakarma, 2020). Similarly, Kalpana Nagari and Kalawati Audi from Godavari Municipality face double discrimination from society for being Dalit and because their relatives tested positive for COVID-19 after returning from India (Chaudhary, 2020). Two recent cases, the killings of six men in Rukum (West), and Angira Pasi in Rupandehi (Shrestha \& Aryal, 2020) are crueler, exposed, and politicized issues, and it 
proved the government incapability to control the discrimination.

\section{Indigenous Peoples}

Indigenous Peoples in Nepal composition for 35.81 percent of the country's total population (CBS, 2012). Despite constituting such a significant portion of the community, they have marginalized in terms of language, culture, and politics as well as economic opportunities throughout history. Official information and communications on COVID-19 are disseminated in the national language and remains mostly inaccessible. So, the main issue regarding COVID-19 is the language barrier as most indigenous communities do not speak the Nepali language, and many are illiterate (IDA, 2020). Similarly, many technical words used, such as self-isolation, social distance, PPE, PCR, etc. are challenging to understand by the indigenous people. Also, indigenous people's issues in relation to Covid-19 are positively affected on their economic, social and health that linked with political decisions. The majority of indigenous people are absolutely concerned by financial crises like joblessness, food crisis, etc. due to COVID-19.

\section{Old age People}

The discourse around COVID-19, in which it perceived as a disease of older people, exacerbates negative stereotypes about older persons who may be viewed as weak, unimportant and a burden on society. Such age-based discrimination may manifest in the provision of services because the treatment of older persons may have perceived to have less value than the treatment of younger generations (UN, 2020). In many countries, including Nepal, older people face the most threats, and challenges during the COVID-19 period. According to the WHO report (2020) over 95\% of deaths occurred in those older than 60 years. More than $50 \%$ of all fatalities involved people aged 80 years or older. In comparison to others, more senior people face a significant risk of developing severe illness if they contract the disease due to physiological changes that come with aging and potential underlying health conditions. The recent cases that appeared in social media, esp. in the news portal, show that people having low immunity power and having chronic disease patients like heart, lungs, high sugar, and high blood pressure, etc., are seen more vulnerable in COVID-19. Hence, the pandemic is more critical for old age people who are above 60 years.

\section{Cultural Effects of COVID-19}

Nepal is not only the land of mountains; it is also the land of feasts, festivals and jatras. There are more than 50 festivals countrywide celebrated in Nepal every year (Nepal Nomad, n. d). The lockdown has shut down the cultural and traditional life of 
the Nepalese people. Many communities - level jatras, pujas, and key festivals have canceled due to the spread of the coronavirus. Even if the celebrations have celebrated in Nepal, small processions have held with masked devotees. This indicates the importance of culture and tradition in this precarious situation that the coronavirus has created. Due to COVID-19, the festivals muted; the songs and music not heard in the alleyway of Kathmandu but complete silence, the silence of cultural cry. This cultural cry was recently converted into aggression when the government failed to coordinate with the concerned stakeholders to conclude the pulling of the chariot of the Rato Machhindranath (Jung, 2020). Later, a symbolic chariot pulling performed after the next violent clash between locals and police, and curfew in the Lalitpur Metropolitan City. Due to lockdown, other jaatra such as IndriJakarta, GayJakarta, BasketJakarta, and festivals like Tee, Chair Dashing, and others like BelauJakarta, Buddha Ajanta, Dalai Lama's Birthday, Jana Purina, Naag Panchami, Krishna Astami, etc., were canceled.

\section{Conclusion}

The pandemic generated impacts mainly from lockdown, curfews, self-isolation, social distancing, and quarantine have affected the overall physical, mental, spiritual, cultural, economic, and social wellbeing of the people of Nepal. The pandemic has generated big questions in the survivors of human life, life patterns of the people, internal, and external connectivity or migration, health facilities and role of government in a pandemic. According to Geltner (2020), this pandemic has raised some critical issues in human history. The painful death may be individual; the current pandemic's impact collectively dovetails with biological and cultural expectations. Many cultures used to older and frailer people dying; only now, it's happening sooner and perhaps more tragically. A large amount of human deaths accelerates the redistribution of wealth and power and alleviate emotional pressures associated with caring for the chronically ill. Both can be defended as sustaining an accepted social order without it is questioned. It also challenging the health system of welfare and socialist states and suggest that resources may redirected to help survivors and attain a new equilibrium in society. Not only these issues, but this pandemic has also devastatingly affected the social, economic, psychological, and cultural life of people and an increase the rate of suicide, girl trafficking, child marriage, and death of old age people. This pandemic also raises the health consciousness among the people the need to protect the environment, traditional human habits, and nature. 


\section{References}

Anderson, B. \& Gouch, J. (2020). Child marriage: Time to reverse the trend, The Himalayan Times. Retrieved from thehimalayantimes.com/opinion/childmarriage-time-to-reverse-the-trend/

Anton, M. (2019). An insider explains the president's foreign policy. Spring 2019 issue of Foreign Policy magazine. Retrieved from https://www.foreignpolicy.com/2019/04/20/the-trump-doctrine-big-thinkamerica-first-nationalism/

Bishwakarma, B. (2020). COVID-19's impact on the Dalit community in Nepal. Retrieved from http://english.lokaantar.com/articles/covid-19s-impact-dalitcommunity-nepal/

Bhattrai, S. (2019). Child marriage in Nepal: eloped at 13, mother by 17. Retrieved from https://www.nepalitimes.com/banner/child-marriage-in-nepal-eloped-at-13mother-by-17/

CBS (2014). Population monograph of Nepal. Central Bureau of Statistics, Ram Shah Path, Kathmandu, Nepal

Chaudhary, U. (2020). COVID-19 sharpens caste discrimination in Nepal. Retrieved from https://www.nepalitimes.com/here-now/covid-19-sharpens-castediscrimination-in-nepal/

Durkheim, E. (1897). Suicide. In Robert Alun Jones (Eds.), Emile Durkheim: An Introduction to Four Major Works. Beverly Hills, CA: Sage Publications, Inc.

Gahatraj, K. (2020). Dalits with disabilities hit hardest by lockdown in Nepal. Retrieved from https://minorityrights.org/2020/08/04/nepal-lockdown/

Geltner, G. (2020). History shows that who dies will matter greatly. Retrieved from https://lens.monash.edu/@politics-society/2020/04/15/1380013/how-covid-19-ischanging-the-world.

Holsten, H. (2020). The politics behind the COVID-19 responses. Retrieved from https://partner.sciencenorway.no/crisis-pandemic-politics/the-politics-behind-thecovid-19-responses/1662531.

IDA (2020). COVID-19 in Nepal: What are the challenges for indigenous persons with disabilities? Retrieved from https://www.indigenousvoice.com/en/indigenous peoples/national.html.

Jung, M. (2020). Impact of COVID-19 pandemic on Nepalese culture and traditions. Retrieved from https://www.peoplesreview.com.np/2020/09/16/impact-of-covid19-pandemic-on-nepalese-culture-and-traditions/ 
K. C., L. (2020). How COVID-19 worsens gender inequality in Nepal. Retrieved from https://thediplomat.com/2020/06/how-covid-19-worsens-gender-inequality-innepal/

Khabarhub (2020). Nepal records 367 rape cases in the last six months; 77 percent of victims are minors. Retrieved from https://english.khabarhub.com/2020/01/138854/

Klein, E. (2020). Corona virus will also cause a loneliness pandemic. Retrieved from https://www.vox.com/2020/3/12/21173938/coronavirus-covid-19-socialdistancing-elderly-pandemic-isolation-quarantine

Lajili, M. (2020). The COVID-19 outbreak's multiple effects. Retrieved from https://www.ijert.org/the-covid-19-outbreaks-multiple-effects, University of Monastir, Department of Physics IPEIM, Tunisia

Mabhubani, K. (2020). A more China-centric globalization. Retrieved from https://foreignpolicy.com/2020/03/20/world-order-after-coroanvirus-pandemic/

Malala Fund (2017). Girls education. Retrieved from https://malala.org/girls-education. Medical Council of Nepal (2019). Registration status in Nepal. Retrieved from https://nmc.org.np/

Menon, S. (2020). This pandemic can serve a useful purpose. Retrieved from https://foreignpolicy.com/2020/03/20/world-order-after-coroanvirus-pandemic/ Ministry of Education (2019). Flash I report 2075 (2018/19). Government of Nepal, Ministry of education, science and technology center for education and human resource development, Babarmahal, Kathmandu.

Nepal Nomad (n. d). Festivals of Nepal. Retrieved from https://www.nepalnomad.com/festivals-of-nepal

Nepal Police (2020). Nepal sees a rise in sexual assault and rape cases. Retrieved from https://www.nepalisansar.com/government/nepal-sees-rise-in-sexual-assault-andrape-cases/

Neupane, A. (2020). At least 20 people committed suicide every day during the lockdown. Retrieved from https://myrepublica.nagariknetwork.com/news/atleast-20-people-committed-sucide-every-day-during-lockdown/

Neupane, P. (2020). Violence against women: Along with Covid-19, another crisis is taking place in Nepal. Retrieved from https://english.onlinekhabar.com/violenceagainst-women-along-with-covid-19-another-crisis-is-taking-place-in-nepal.html PiN (2020). Impact of Covid-19 measures on vulnerable communities in earthquakeaffected areas needs assessment report. Retrieved from https://reliefweb.int/sites/reliefweb.int/files/resources/ 
Poudel, K. \& Subedi, P. (2020). Impact of COVID-19 pandemic on socioeconomic and mental health aspects in Nepal, IJSP. Retrieved from https://doi.org/10.1177/0020764020942247.

Poudel, A. (2020). Health workers under attack as lack of Covid-19 awareness is fuelling stigma, Kathmandu post. Retrieved from https://tkpo.st/2EbzmTb

Karki, S. (2020). Lockdown period: No abatement of minors' sexual abuse. Retrieved from https://risingnepaldaily.com/detour/lockdown-period-no-abatement-ofminors-sexual-abuse.

Shakya, M. (2020). The politics of border and nation in Nepal in the time of pandemic. Retrieved from https://link.springer.com/article/10.1007/s10624-020-09599-x

Sharma, N. (2020). Child marriages up during Nepal lockdown. Retrieved from https://www.nepalitimes.com/latest/child-marriages-up-during-nepal-lockdown/

Shrestha, E. \& Aryal, A. (2020). Discrimination against Dalits continues to stain Nepal's social fabric. Retrieved from https://tkpo.st/3cnsixC

Staples, J., \& Widger, T. (2012). Situating suicide as an anthropological problem: Ethnographic approaches to understanding self-harm and self-inflicted death. Cult Med Psychiatry 36, 183-203 (2012). https://doi.org/10.1007/s11013012-9255-1

UN (2020). Everyone included: Social impact of COVID-19. Retrieved from https://www.un.org/development/desa/dspd/everyone-included-covid-19.html UNDP (2020). Rapid assessment of the socio - economic impact of covid-19 in Nepal. Prepared by IIDS, www. np.undp.org.

UNPFA (2020). Impact of the COVID-19 pandemic on family planning, and ending gender-based violence, female genital mutilation and child marriage. Retrieved from https://www.unfpa.org/resources/impact-covid-19-pandemic-familyplanning-and-ending-gender-based-violence-female-genital.

Walt, S. M. (2020). How the world will look after the coronavirus pandemic. Retrieved from https://foreignpolicy.com/2020/03/20/world-order-after-coroanviruspandemic/

World Bank (2020). Nepal steps up remote learning during COVID-19. Retrieved from https://blogs.worldbank.org/endpovertyinsouthasia/nepal-steps-remote-learningduring-covid-19

World Health Organization (2020). Suicide prevention. Retrieved from https://www.who.int/health-topics/suicide

World Health Organization (2020). Supporting older people during the COVID-19 pandemic is everyone's business. Retrieved from https://www.euro.who.int/en/health-topics/health-emergencies/coronavirus- 
covid-19/news/news/2020/4/supporting-older-people-during-the-covid-19pandemic-is-everyones-business

World Health Organization (2020). Outbreak of pneumonia caused by new Coronaviruses. Retrieved from https://www.who.int/ith/2020-24-01-outbreakof-Pneumonia-caused-by-new-coronavirus/en/ .

Worldometer (2020). COVID-19 coronavirus pandemic. Retrieved from https://www.worldometers.info/coronavirus/\#countries. 